\title{
Principal Strategy for Improving the Quality of Teachers
}

\author{
Hadi Yanto ${ }^{1 *}$, Happy Fitria ${ }^{1}$, Rohana ${ }^{1}$ \\ ${ }^{1}$ Universitas PGRI Palembang, Indonesia \\ *Corresponding author. Email: hadiyantonasuhak096@gmail.com
}

\begin{abstract}
The aim of this study was to describe and analyze: (1) the main quality improvement strategy for SD Negeri 3 Rambang Dangku, Muara Enim; (2) Restrictions on the principle of quality improvement in SD Negeri 3 Rambang Dangku, Muara Enim; (3) solutions in improving the quality of SD Negeri 3 Rambang Dangku, Muara Enim. The method used in this research is part of the qualitative descriptive research group. The results of this study include: (1) the leadership strategy to improve the quality of teachers at SD Negeri 3 Rambang Dangku has been carried out with a properly implemented strategy; (2) the main obstacle to improving the quality of education is that there are still teachers who have little awareness of improving the performance of teachers, and (3) the solution adopted by the Principal of SD Negeri 3 Rambang Dangku to overcome the constraints of improving teacher performance is to make continuous efforts to overcome existing barriers by holding peer tutors between teachers to overcome barriers to how many teachers who are not fluent in the use of ICT.
\end{abstract}

Keywords: Strategy, Principal, Improvement, Teacher Quality

\section{INTRODUCTION}

In the face of an era of technological disruption and globalization, it is necessary to improve the quality of education as a vehicle for building and forging the quality of human resources. This human quality is produced by the provision of quality education. In an effort to improve the quality of national education, the government continues to make a number of changes and reforms to our education system, in particular through the Ministry of National Education (Depdiknas). One of the efforts that has been and is being made has to do with the teacher factor.

Teachers are one of the key components of the teaching and learning process that play a role in the development of potential human resources. Teachers are one of the elements in the field of education that must play an active role and position themselves as professionals in line with the demands of an increasingly developing society. In this case, the teacher is not just a knowledge transfer teacher, but also a value transfer educator as well as a mentor who guides and guides students in learning. The completeness of the number of teachers and the quality of teachers will have an impact on the success of students in learning, which will lead to an increase in the quality of education. For this reason, teachers are required to be more professional or qualified in the performance of their duties.

Sutarmanto said that the role of the teacher is very important in the management of the classroom, because the teacher is in charge of teaching and learning activities in the classroom. This is very reasonable, because the training of students' knowledge, skills and character can be achieved through the management and learning of the classroom by the teacher. As a result, qualified teachers will perform and demonstrate professional performance in their duties. This type of performance will result in a quality learning process, quality learning outcomes and quality graduates that have an impact on the quality of education [1].

According to [2], the principal is one of the components of education that has an impact on improving the performance of teachers. The school principal shall be responsible for the implementation of educational activities, school administration, coaching of other educational staff, and the use and maintenance of facilities and infrastructure. This becomes more important in line with the increasingly complex demands of the principal's duties, which require more effective and efficient support for performance [2]. 
In line with this, the direct responsibility of the school principal as school leader and manager is to improve the quality at the level of the educational unit. The quality assurance organization in the education unit is therefore directly under the responsibility of the school principal. It is therefore clear that the direct responsibility of the school principal is to improve the quality of education in schools, including the quality of teachers. Particularly in order to improve the quality of teachers, it is the responsibility of the Principal to implement the mapping needs of teachers, to meet the needs of teachers, to assign teachers, to assess teachers, to coach and develop teachers and to report to school teachers [3].

To carry out the responsibility for improving the quality of teachers, of course, a principal who has professional abilities is needed in improving the quality of teachers. Principal professionalism is needed in schools for the success of improving the quality of teachers and the quality of education as a whole. Without the professionalism of teacher quality, learning in schools will continue to take place. With the qualifications and competences of principals, namely personality, managerial, entrepreneurial, supervisory, and social, the performance of the principal will be professional, and the professionalism of the principal is shown by the presence of the right strategy to develop and improve the quality of teachers in his school [4].

According to [6] the strategy is a comprehensive plan that integrates all the resources and capabilities that have the long-term goal of winning the competition. Strategy is also a powerful and unavoidable instrument of governance, not only for survival and competition, but also for growth and development. The importance of the education strategy can also be seen from the following points [5]: 1) The strategy sets out the direction for the long road to be followed; 2) Helping educational institutions adapt to the changes that have taken place; 3) to make educational institutions more efficient; 4) Identifying the comparative advantages of education institutions in an increasingly risky environment; 5) strategy-making activities will enhance the ability of educational institutions to avoid potential future problems; 6) Involvement of educators in the development of strategies will further motivate them at the implementation stage; 7) Less overlapping activities will occur; and 8) the lack of willingness to change from old educators can be reduced [6].

It is clear from the above description that the Principal must be able to develop a quality strategy for teacher development that will improve the quality of the school. The achievement of the quality of the teacher depends very much on the skills and abilities as well as on the leadership of the school principal, because the principal who manages the resources of the teacher who is gradually and continuously owned is responsible for the achievement of the established quality standards. The quality standards for education in Indonesia are laid down in the National Standard and are known as the National Standards for Education. Pursuant to the Government Regulation of the Republic of Indonesia No 19 of 2005 on National Education Standards, Article 1(1) [7] provides that: "National Education Standards (SNP) are the minimum criteria for the education system in all jurisdictions of the Republic of Indonesia". The National Education Standards shall include: standards for content, standards for processes, standards for graduate skills, standards for teaching and teaching staff, standards for facilities and infrastructure, standards for management, standards for financing and standards for educational assessment. With the stipulation of these eight standards, the aim of improving the quality of education in schools must also be to focus on these eight standards, one of which is the standard for educators and educational staff.

Based on the results of the preliminary observations and interviews conducted on 2 September 2020 at SD Negeri 3 Rambang Dangku Muara Enim, various efforts to improve the quality of teachers have been made by the director of SD Negeri 3 Rambang Dangku Muara Enim, including by improving the professionalism of teachers through a number of school-based training sessions, and by conducting educational management. This indicates that the Principal has planned and implemented teacher quality improvements for SD Negeri 3 Rambang Dangku Muara Enim.

However, various efforts to improve the quality of teachers have not shown significant results for the quality of teachers at SD Negeri 3 Rambang Dangku Muara Enim. At SD Negeri 3 Rambang Dangku Muara Enim, teaching and learning management skills are still low, both in terms of the ability to plan teaching and learning programs, the ability to interact or manage the teaching and learning process, and the ability to carry out assessments. In terms of professionalism, teachers have also not shown the ability to master the most recent lessons, have not mastered and understood the foundations and insights of education and teacher training. In addition, it was also found that the teachers did not demonstrate disciplined attitudes and behaviors in the performance of their duties.

In fact, the current position of a teacher is a position that has a major role to play by teachers in achieving a better quality of education. Teachers as employees are required to have professional skills or competencies. Teacher professionalism is often linked to three important factors, namely teacher competence, teacher certification and professional allowances. These three factors are the background that is said to be closely related to the quality of education. Professional teachers have proven their skills that will encourage the implementation of performance processes and products 
that can support the improvement of the quality of education. Competent teachers have been shown to have mastery of four types of competencies, namely (1) pedagogical competence (2) professional competence, (3) social competence and (4) personality competence.

Teacher competencies above must be encouraged to be mastered by facilitating the improvement of teacher quality. This needs to be considered by a number of stakeholders, because the success of education is largely determined by the quality of teachers. The strategic position of teachers to improve the quality of education outcomes is strongly influenced by the professional skills of teachers and the quality of teachers themselves [8].

The birth of Law No. 14 of 2005 is an effort to improve the quality of teachers while, at the same time, it is hoped that it will improve the quality of education in Indonesia. The law requires teachers to have academic qualifications, competencies, certificates of teaching, to be physically and mentally sound, and to be able to achieve the objectives of national education. Increased qualifications, increased competence, teacher certification, career development, reward and protection, teacher planning needs, teacher allowances and additional benefits are the current priority policies for empowering teachers.

It is clear that efforts to improve the quality of teachers are influenced by a number of factors. One factor affects the other factors. The most important factor, however, is the teacher, because the black and white of the teaching and learning process in the classroom is largely influenced by the quality of the teacher. Various problems in improving the quality of teachers are due to the lack of ownership and implementation of the various strategies of the quality improvement principle. One of the strategies for improving the quality of teachers that can be implemented by the principal of the funds is selfassessment for improving the quality of teachers, planning and implementing strategies for improving the quality of teachers, monitoring and evaluating strategies for improving the quality of teachers, as well as understanding the various constraints and finding solutions for improving the quality of teachers [9]. The strategy of the Principal to improve the quality of teachers relates to the conceptual skills that the Principal must have. With its conceptual skills, school principals are formulating appropriate, effective and efficient strategies to improve the quality of teachers in their schools.

\section{METHODS}

This research will be conducted at SD Negeri 3 Rambang Dangku Muara Enim, located in Banuayu Village, Rambang Niru District, Rambang Dangku
Regency, Muara Enim, South Sumatra. This research will take place from October to December 2020. This research is part of the qualitative descriptive research group.

This research focuses on the main strategy for developing the quality of teachers, which consists of several components that need to be improved, including teacher performance, material/curricular mastery, the use of teaching methods, the use of stationery/educational facilities and the implementation of curricular and extracurricular activities at SD Negeri 3 Rambang Dangku Muara Enim.

The data collection procedure uses the observation, interview and documentation method. Data analysis technique used data reduction, data presentation and drawing of conclusions. In the meantime, check the validity using the triangulation method.

\section{RESULTS AND DISCUSSION}

\section{Principal leadership strategy to improve the quality of teachers at SD Negeri 3 Rambang Dangku}

The Principal's leadership strategy is one of the main approaches used to achieve school goals, including ways to improve teacher performance in the learning process, as well as the Principal's leadership strategy to improve teacher performance at SD Negeri 3 Rambang Dangku, namely:

\section{A. Direct coaching to improve teacher performance in SD Negeri 3 Rambang Dangku}

Understanding teacher performance is the maximum capacity of teachers to carry out tasks and responsibilities in the learning process, such as planning, implementing and evaluating learning outcomes so that they can be realized, teaching performance is the effort or work of teachers in the teaching and learning process in a professional and quality way based on their expertise as teachers. As for something that can be achieved by a teacher in the performance of his or her duties and in the achievement of his or her teaching and education objectives, the activities to be carried out will complete tasks and responsibilities in accordance with the expectations and objectives that have been set.

Improving teacher performance in the classroom is an effort made by the principal to carry out direct coaching by going around the classroom to see teachers doing teaching and learning activities in the classroom. The role of the principal in improving teacher performance through direct coaching was thus played by SD Negeri 3 Rambang Dangku. Teachers of SD Negeri 3 Rambang Dangku understands that this is one of the efforts made by the Principal to improve the performance of teachers in learning as long as the 
Principal of SD Negeri 3 Rambang Dangku seeks the support of teachers, as this will have implications for improving the performance of teachers in school.

The aim of the direct implementation of teacher coaching is to improve the performance of teachers equally so that the process of learning activities can be carried out smoothly. Direct coaching by the principal is carried out in stages, due to the large number of teachers and the limited time of implementation.

(a) Increased attendance of teachers; (b) Learning equipment becomes a concern; (c) Teaching preparation begins to be organized; (d) The concern for facilities and the school environment is considered; and (d) Facilities and school culture are more organized. Changes are seen after direct coaching by SD Negeri 3 chief Rambang Dangku.

\section{B. Teachers' Meeting Discusses Teacher Performance Improvement at SD Negeri 3 Rambang Dangku}

Teacher meetings are held to provide the principal's explanations for the meeting activities, not only to listen to the explanations of the meeting leader, but also to provide the opportunity to ask questions, meetings are held to find solutions to the problems at hand. This teacher meeting activity is of great benefit because it can provide input in the form of suggestions or opinions and share experiences between one teacher and another, share how to practice the most recent applications in order to face challenges in teaching and learning activities such as online or online learning.

The Principal of the School held regular meetings of the teachers and, if there are problems faced by the teachers of SD Negeri 3 Rambang Dangku, the Principal invites discussions in order to solve the problems faced. In this activity, teachers will help each other and work together if there are difficulties in teaching and learning activities.

The holding of teacher meetings can improve the performance of teachers in learning activities at SD Negeri 3 Rambang Dangku, which is quite a challenge because students who attend SD Negeri 3 Rambang Dangku come from different groups, both economically and in the environment. After the teacher meeting has been held, the current challenges can be overcome by solving problems together through the discussion forums.

\section{Teacher Working Group (KKG)}

The Teacher Working Group (KKG) as a forum for the activities of teachers who are members of a cluster to improve their professionalism together, KKG works to help teachers carry out various teaching and learning activities, including the planning of teaching and learning strategies, the development of learning tools, the preparation of workbooks and the discussion of problems encountered in each class.

In order to improve the performance of teachers, the Government, in this case the Ministry of National Education, stressed that teachers and other education personnel are expected to improve their professional skills. The means to improve the performance of elementary school teachers is through the activities of the working groups of teachers (KKG). The existence of a Teacher Activity Center (PKG) in the Professional Development System, particularly in the Department of Education and Culture, already exists.

The activities carried out at the KKG include addressing problems related to the learning process and difficulties faced by teachers, including: 1) preparation of tools for learning (annual program, semester program, syllabus, time allocation, lesson plans, assessment); 2) the Media Learning; 3) the method of learning, and 4) the assessment.

The most frequently discussed activities of the KKG include the 2013 curriculum, as all schools have implemented learning with the latest curriculum, what is often discussed is the development of a one-size-fits-all Learning Implementation Plan (RPP) where the Learning Implementation Plan (RPP) can reach 3 to 4 sheets at one meeting, but once the Learning Implementation Plan (RPP) has been changed to one more sheet and is more effective in its manufacture, then what is often discussed is also the 2013 Curriculum Assessment, because the 2013 Curriculum Assessment always changes and is written because the 2013 Curriculum Report Cards assess numbers and descriptions on the basis of the core competencies that have been studied, to make it easier to type the report cards into the 2013 curriculum using the applications, the 2013 Curriculum Assessment is also frequently discussed, because the 2013 Curriculum Assessment always changes and is written because the 2013 Curriculum Report Cards assess numbers and descriptions on the basis of the core competencies that have been studied, to make it easier to type the report cards into the 2013 curriculum using the applications, and this is what requires special training to ensure that there are no obstacles at the time of typing, while the report card sheets are using paper scraps. A special bag that has the label and symbol of the school area concerned, so that the report cards must be carefully typed. SD Negeri 3 Rambang Dangku participated in the KKG by assigning teachers in turn so that all teachers had the opportunity to know and learn what was said at the KKG meeting. 


\section{Participation in a training/workshop to improve the quality of teachers at SD Negeri 3 Rambang Dangku}

Teacher training/workshops will provide benefits and make it easier for teachers to do their job. Training/workshops also help teachers develop their skills in a better way to complete a job. d. Participation in a training/workshop to improve the quality of teachers at SD Negeri 3 Rambang Dangku.

Teacher training/workshops will provide benefits and make it easier for teachers to do their job. Training/workshops also help teachers develop their skills in a better way to complete a job. Teacher performance is related to the quality of education, and increasing the performance of teachers has a major impact on the development of students. Training/workshops improve the quality of themselves to carry out tasks related to learning process activities, and students will be able to learn if the teacher is of good quality. One of the good qualities can be achieved through training/workshops.

Training/workshops are providing training to participants on theory and practice in the field. Or, in other words, training/workshops, that is, training for participants who work individually or in groups to solve problems related to actual work/tasks in order to gain experience. A workshop event is a meeting place for people who have the same interests and expertise in certain fields to come together in order to be able to follow expert directions to discuss the issue.

The Principal of the School assigns teachers who have been included in training/workshops, seminars and workshops to learn through training/workshops. After completion of the training, the teachers who participated in the training/workshop conveyed or applied their knowledge to other teachers who did not participate in the workshop. As a result, the results obtained by the assigned teacher training/workshop are also obtained by teachers who are not assigned by monitoring by teachers who participate in the training/workshops. Teachers who have finished participating in activities such as training/workshops and seminars to explain and report on the results to the Principal in particular and to teachers in general, it is intended that the material and knowledge acquired may be transmitted to other teachers. Therefore, the results obtained by the teacher training / workshop assigned are also obtained by teachers who are not assigned by monitoring carried out by teachers participating in training / workshops.

Teachers who are assigned to participate in the training/workshop activities shall be appointed on a rotational basis, after completing the training/workshop activities, to imitate the knowledge acquired during the workshop for teachers who do not participate in the training/workshop activities. These activities may be carried out by educational units, cluster activities in subdistricts or at school meetings of teachers.

SD Negeri 3 Rambang Dangku has implemented an increase in teacher performance through training/workshops, including teachers in training programs/workshops, which are held independently and some are assigned to the Education and Culture Office of Muara Enim City. This can be seen by increasing teacher performance in the management of classroom learning.

\section{E. Giving Motivation to Teachers}

Motivation is an incentive that grows and develops to do the best possible work so that the desired goal can be achieved, motivation can occur if a teacher is proud of the success that has been achieved.

The leadership strategy implemented by the director of SD Negeri 3 Rambang Dangku is such that the teachers of SD Negeri 3 Rambang Dangku are eager to improve their performance. The strategy of providing motivation to teachers of all parties in the school really appreciates this activity, because for teachers and students who have achieved success, classroom facilities are equipped to meet the needs of students and teachers if the teacher succeeds in achieving impressive performance. Rewards are given by the Principal to teachers and students who are able to perform both in and out of school in the form of cluster, sub-district, city, provincial or central level competitions. The strategy adopted by the Principal to motivate teachers and other students may encourage them to compete for achievement.

\section{F. To give appreciation to the teacher}

Teacher appreciation is a necessity, there are several features to make Human Resources (HR) work better, namely necessity. These needs have levels, namely: a) physiological needs; b) security needs; c) affection needs; d) self-esteem needs, and e) the need for opportunities.

The award by the director of SD Negeri 3 Rambang Dangku was made not only in the form of goods or money, but with praise, in accordance with the needs of love, self-esteem and the availability of opportunities to improve the performance of teachers. Giving awards is also an incentive to work because schools and principals have an important role to play in fostering enthusiasm for work, one of which is by giving awards with praise.

Granting awards to the teacher is given directly or indirectly by the principal, and awards are usually given face-to-face with the teacher or through the whatsaap group when the teacher uploads learning activities through various applications and at teacher meetings. Indirect awards shall be made by the Deputy Principal or other teachers. This is usually done when the principal has an activity in the teacher's room. Giving 
awards with praise can improve the performance of teachers at SD Negeri 3 Rambang Dangku, because awards with praise can be directly imitated by other teachers, so that teachers at SD Negeri 3 Rambang Dangku have a good performance and are more enthusiastic about carrying out activities that can increase the motivation of teachers and improve the quality of education in schools.

\section{G. Supporting Facilities Available}

Supporting facilities are one of the efforts that can facilitate and smooth the implementation of learning activities, because with adequate support facilities it is a supporting factor for teacher performance in student learning outcomes, so learning support facilities must refer to learning objectives, use of learning support facilities if they are effectively implemented. And to improve the process of student learning activities effectively.

To support teacher performance, SD Negeri 3 Rambang Dangku's learning activities include libraries, the Internet, and reference books. The priority of the school principal, however, is the Internet facility so that teachers can access the latest information because 19 pandemic learning activities were carried out online during COVID. The need for an internet quota is growing. Because teachers and students are doing distance learning.

Teachers use these facilities to make learning vedios available through a variety of applications, including: whatsaap, zoom, google meet, telegram, and many other applications that can help teachers convey student learning materials to the fullest. Online learning is a learning method that uses an internet-based interactive model, using a computer or a cell phone connected to an internet network, to solve learning problems in SD Negeri 3 Rambang Dangku is done remotely, i.e. online because online learning can overcome distance learning, because it must be adapted to the conditions of the student's living environment, which is far from causing distance learning.

Books in the library are also used by teachers to provide a lot of inspiration, the benefits of reading books include a) adding insight, b) being open-minded, c) a lot of inspiration. Therefore, the Principal of SDN 1 encourages teachers and students to cultivate reading carts for students and teachers, as well as to always try to add references to the books needed by students and teachers to support the improvement of teacher performance in order to increase teacher insights into the provision of student learning materials.

\section{H. Advanced Studies.}

Further studies are being carried out to improve the academic qualifications of the teacher, in particular for teachers who will be certified by the teacher in office. In addition, further study is also beneficial to the scientific development of a teacher. The Director of SDN I Kota strongly supports the follow-up study activities carried out by SD Negeri 3 Rambang Dangku teachers. A further study conducted by SD Negeri 3 Rambang Dangku Teachers to improve the quality of teachers, the quality of teachers is people who are well educated and trained and who have the skills and expertise in the field of teacher training in order to maximize the quality of teachers significantly affects the performance of teachers.

The Principal of SD Negeri 3 Rambang Dangku always encourages teachers at SD Negeri 3 Rambang Dangku to carry out further studies and already 3 teachers at SD Negeri 3 Rambang Dangku have completed their Master's degrees and 5 teachers are still in the process of pursuing S2 education at a cost of their own. Further studies can improve a teacher's thinking, as a teacher can add insight into managing learning management in the classroom by participating in lecture activities. Teachers who continue to study at a higher level so that they have more knowledge as a means to carry out their duties at school.

\section{The Principal Leadership Strategy Constraints on Improving the Quality of Teachers at SD Negeri 3 Rambang Dangku}

In any of the various activities that are being managed, it is certain that there will be obstacles in the field as well as the implementation of the Principal Leadership Strategy to improve teacher performance, including the main leadership strategy for SD Negeri 3 Rambang Dangku, which is also not free from obstacles.

An important part of this is the training of professional teachers with the main task of educating, teaching, guiding, guiding, training, evaluating, and a sense of responsibility in the performance of tasks characterized by expertise, both in the delivery of materials and in the use of methods. Personal, social, intellectual, moral and spiritual, and a sense of community, that is, a sense of community among fellow teachers. In the meantime, the achievement of teacher performance is supported by a spirit of professionalism. The spirit of professionalism is a mental attitude that always encourages you to be a professional teacher. In addition, the quality of professionalism can be demonstrated in the following ways of thinking and working behaviour: (a) The desire to always display behavior that is close to the ideal standard; (b) Improve and maintain the image of the profession; (c) the desire to pursue professional development opportunities on an ongoing basis; (d) Pursuing the quality and ideals of the profession, and (e) To have pride in their profession.

With a spirit of professionalism, a sense of responsibility for the performance of teachers will grow, consisting of learning planning, learning, assessment 
and guidance. There are many ways to improve teacher performance. But all this is going back to the human factor that runs it. People who are in an educational environment must therefore try to be professional. The key players in improving teacher performance in schools are the principal as the school manager and the teacher as the learning manager. Supervision at the beginning of the preparation can minimize the possibility of failure that can occur when the implementation of school activities in the future [10].

The results of the research identified the barriers faced by the principal of SD Negeri 3 Rambang Dangku in improving the performance of teachers, namely: (a) There are still some teachers who are not capable of using ICT; (b) lack of mastery of materials or references, so that the improvement in the performance of teachers is somewhat hindered, and (c) less efficient use of learning time still exists for teachers who are less competent to provide learning.

The existence of some of these barriers makes it impossible to maximize the leadership strategy for improving teacher performance, and as expected, the main objective is to seek solutions in a variety of ways so that the performance of SD Negeri 3 Rambang Dangku teachers can be properly and smoothly implemented so that the desired objectives can be achieved.

\section{The Principal Solution to Overcome Obstacles to Improve Teacher Performance in SD Negeri 3 Rambang Dangku}

In discussing school principal solutions to overcome barriers to improving teacher performance by SD Negeri 3, Rambang Dangku has made a number of efforts. From the efforts made by the director of SD Negeri 3, Rambang Dangku is the action of a leader who has the task and responsibility of managing the school, collecting, utilizing and mobilizing all the potential of the school in an optimal way to achieve its objectives. As a manager, the principal has the right to supervise the performance of the teacher, whether the teacher has performed his function properly. Through this supervision, it is hoped that there will be communication between teachers and school principals as to what is different from the performance of teachers and what can be further improved. In this way, teachers can determine the direction of better performance in order to achieve educational success. There are forms of supervision that can be implemented, such as classroom learning, administration, and teacher performance activities.

The conditions in SD Negeri 3 Rambang Dangku are that there are some teachers who are not fluent in the use of ICT, lack of materials or references in learning, and inefficient use of learning time, which means that there are obstacles to increasing the performance of teachers, so that the program that the school wants to achieve is slow in achieving its desired objectives will have a direct impact on the learning process that should be pursued. Similarly, the educational atmosphere that challenges and motivates creative students cannot be applied.

The solutions made by the Principal of SD Negeri 3 Rambang Dangku in overcoming the obstacles to improving teacher performance were:

\section{Peer Tutor}

Peer tutors are learning with their own friends to eliminate embarrassment for those who are embarrassed to ask questions, peer tutors can act as group leaders, their task is to help friends who face learning difficulties or, in other words, peer tutors, that is, to provide assistance to someone who has high absorption of friends who don't understand.

This peer tutor is programmed by the director of SD Negeri 3 Rambang Dangku to help teachers who are not yet fluent in ICT use, guided by teachers who are already able to use ICT well, this peer tutoring activity is carried out on an ongoing basis every day, even every time by sharing information through whatsaap group, SD Negeri 3 Rambang Dangku has several whatsaap groups, namely: school whatsaap group, class whatsaap group, committee whatsaap group, exchange information in this group using the ICT application.

Teachers who are already fluent in the use of ICT are assigned to SD Negeri 3 Rambang Dangku by taking part in online training/workshops so that ICT knowledge can be improved again. The use of ICT is carried out on a gradual and continuous basis, whether by assigning the teachers concerned to take part in online training through various applications or individually.

\section{Team Work}

Team work can also be interpreted as teamwork or teamwork, which is a form of group work with complementary skills and commitment to achieving the agreed targets before achieving the desired objectives, but can also involve receiving and providing assistance to other team members to complete the burden of work. When the team has completed the work assigned to it while the other team members have not finished, the team that has completed the work helps the team that has not been completed.

There are obstacles that some teachers do not master the material and the references, not because the teacher lacks knowledge of the learning material to be presented, but because the teacher does not prepare the learning material from the outset, so that at the time of the learning process the teacher seems to be less familiar with the learning material. 
Continuous direct guidance provided by the Principal by inviting teachers to continue learning, discussions and discussions at routine teacher meetings, meetings of teachers to discuss the issue of not mastering the materials or references to learning activities faced by teachers in an effort to improve performance and practice in order to improve the learning process for students through the team work.

The Principal's leadership strategy, carried out by the Principal in overcoming the constraints of the lack of teachers in mastering materials or references, has gradually and gradually been carried out through the daily routine of preparing learning materials from scratch and discussed and practiced in peer-training activities where the formation of Teamwork begins with a low-class, high-class name.

The collaboration of the six teams shall be carried out in collaboration with their own groups which have been formed. By sharing tasks and helping each other out. This teamwork activity is monitored directly by the principal and vice-principal, and after the teacher has completed the results of their teamwork, the results are reported through the WhatsApp school group. The formation of 6 team work in which homeroom teachers cooperate with each other and share workloads to facilitate the delivery of learning materials so that teachers who do not master materials or references can provide materials or references in a smooth manner.

At the teacher meeting, the activities discussed the performance issues of the teachers at SD Negeri 3 Rambang Dangku. As well as showing the results of the team work carried out by the 6 teamwork that has been done. This activity is strongly supported by the teachers of SD Negeri 3 Rambang Dangku, as it can reduce the individual workload of each teacher. This strategy is already in place and can help to overcome the problem of some teachers who do not master learning materials and who can share workloads with teachers who already understand how to make learning materials more efficient.

\section{Giving trust full responsibility}

When providing learning, it should be done on time, because it will have fatal consequences for students and students in the conduct of learning, because the principal will deal with disciplinary guidance that is conveyed directly when conducting direct coaching or delivered in meetings, with the hope that some teachers who are less disciplined will be able to implement the rules that have been mutually agreed upon.

If the learning starts on time, the results will be maximized and the lessons will not be shortened, and the students are still focused on the lessons they teach, and the teacher must also prepare the material to be taught so that the learning can run smoothly. Study time is from 07.00 WIB to 12.10 . WIB.
By giving full responsibility to some teachers who often use less efficient learning time, so that the teacher can reduce his lack of discipline, become a sense of responsibility or trust, and provide advice and exercise a high level of discipline so that good discipline can be applied to teaching and learning activities at school.

\section{CONCLUSION}

The results of this study include: 1) The main leadership strategy for improving the quality of teachers at SD Negeri 3 Rambang Dangku has been well implemented, strategies have been implemented, namely: a) Direct guidance on the performance of teachers at SD Negeri 3 Rambang Dangku, b) monthly meetings to discuss improving the performance of teachers in SD Negeri 3 Rambang Dangku, c) Teacher Working Group (KKG) d). Participate in training/workshops, (e) motivate teachers, (f) reward teachers, (g) further study. Principal of SD Negeri 3 Rambang Dangku carried out direct coaching to assess the quality of teachers at SD Negeri 3 Rambang Dangku as having an effect on the back and forth of the school being run either because it affects teachers and the teaching and learning process that takes place every day for the principal; 2) the main obstacle to improving the quality of education is that there are still teachers with low awareness of improving teacher performance among: a) there are some teachers who are not fluent in ICT use, b) lack of mastery of materials or references, c) less efficient use of time; 3 ) the solution adopted by the Principal of SD Negeri 3 Rambang Dangku to overcome the constraints of improving teacher performance is to make continuous efforts to overcome existing barriers by holding peer tutors between teachers to overcome barriers to how many teachers are not fluent in the use of ICT. In the case of teachers who do not master materials or references, teamwork is formed and does not use effective time to overcome them by giving trust and advice, so that teachers can prepare learning materials before learning activities take place in the classroom. In order to increase the barriers that can be overcome by the performance of teachers at SD Negeri 3 Rambang Dangku, and to achieve educational objectives, according to the program that has been planned.

\section{ACKNOWLEDGMENT}

Our deepest gratitude goes to Chancellor of PGRI Palembang University, Director of the Postgraduate Program of PGRI Palembang University and the Education Management Study Program of PGRI Palembang University, who have supported us in doing this extraordinary thing. This project is funded independently. We also want to thank our Education Management friends who helped us a lot in a short time frame to complete this project. 


\section{REFERENCES}

[1] Sutarmanto. (2015). Kompetensi Dan Profesionalisme Guru [Teacher Competence and Professionalism]. Jurnal Visi Ilmu Pendidikan.

[2] Mulyasa. (2013). Pengembangan dan Implementasi kurikulum 2013 [Development and Implementation of the 2013 curriculum]. Bandung: Remaja Rosadakarya.

[3] Saifulloh, M., Muhibbin, Z., \& Hermanto, H. (2012). Strategi Peningkatan Mutu Pendidikan Di Sekolah [Strategy to Improve the Quality of Education in Schools]. J. Sos. Hum., 2012, doi: 10.12962/j24433527.v5i2.619.

[4] Lailatussaadah, L. (2015). Upaya Peningkatan Kinerja Guru [Strategy to Improve the Quality of Education in Schools]. Jurnaal Intelektualita vol 3 (1).

[5] Teece, D. J., Pisano, G., \& Shuen, A. (1997). Dynamic capabilities and strategic management," Strateg. Manag. J., doi: 10.1002/(SICI)10970266(199708)18:7<509::AID-SMJ882>3.0.CO;2-

$\mathrm{Z}$.

[6] Sagala, S. (2018). Pendekatan \& Model Kepemimpinan [Leadership Approach \& Model]. Jakarta: Prenadamedia Group.

[7] Kementerian Pendidikan. (2005). Peraturan Pemerintah Republik Indonesia Nomor 19 Tahun 2005 [Government Regulation of The Republic Of Indonesia Number 19 Year 2005]. Prod. Huk. tentang Standar Nas. P, 2005.

[8] Farisi, M. I. (2011). Kompetensi Guru dalam Mewujudkan Pendidikan Berkarakter dan berbasis Budaya [Teacher Competence in Realizing Character and Culture-based Education]. J. Teknol. Pendidik.

[9] Maris, I. S., Komariah, A. \& Bakar, A. (2016). Kepemimpinan Transformasional Kepala Sekolah, Kinerja Guru Dan Mutu Sekolah [Principal Transformational Leadership, Teacher Performance and School Quality]. J. Adm. Pendidik., doi: 10.17509/jap.v23i2.5645.

[10] Sarbini., Kristiawan, M., \& Wardiah, D. (2020). Supervisor's Performance for the Quality of Education. International Journal of Progressive Sciences and Technologies (IJPSAT), 20(1), 255262. 